\title{
Germanica
}

les pays germanophones de 1880 à nos jours

\section{Annick Carlier aux côtés des étudiants}

\section{Amar Halit}

\section{(2) OpenEdition}

\section{Journals}

Édition électronique

URL : http://journals.openedition.org/germanica/5069

DOI : 10.4000/germanica.5069

ISSN : 2107-0784

Éditeur

Université de Lille

\section{Édition imprimée}

Date de publication : 31 juillet 2018

Pagination : 11

ISBN : 9782913857414

ISSN : 0984-2632

\section{Référence électronique}

Amar Halit, "Annick Carlier aux côtés des étudiants », Germanica [En ligne], 62 | 2018, mis en ligne le 31 juillet 2018, consulté le 15 janvier 2021. URL : http://journals.openedition.org/germanica/5069 ;

DOI : https://doi.org/10.4000/germanica.5069 


\section{Annick Carlier aux côtés des étudiants}

Ce n'est certainement pas exagéré de dire qu'Annick fait partie des gens qui ont le plus changé le cours de ma vie ici, en France. Je l'ai d'abord connue en tant que bibliothécaire à mon arrivée en France puis comme ma responsable quand elle m'a recruté en tant que moniteur de bibliothèque à l'UFR. J'ai appris d'elle énormément de choses. Je pense pouvoir parler au nom des étudiants qui l'ont connue si je dis qu'elle fut une bibliothécaire très agréable, qui maîtrisait parfaitement son métier et qui, par sa profonde connaissance du fonds de la bibliothèque, sut toujours répondre à nos demandes. Ses cours de méthodologie documentaire ont aidé des générations d'étudiants à mieux se repérer dans leurs études, son investissement dans la diffusion du savoir porte et portera encore longtemps ses fruits.

Annick fut aussi une responsable exceptionnelle. Elle créait une atmosphère de travail très amicale. Profondément soucieuse de l'égalité entre ses moniteurs, elle se montrait très flexible et compréhensive. À mon sens, sa gentillesse et sa générosité furent exemplaires, sa modestie rare, sa curiosité pour le savoir contagieuse. Annick nous adressait des emails qui commençaient par « Mes chers amis ». Annick apporta tant aux étudiants, à ses moniteurs, aux enseignants-chercheurs de l'UFR. C'est une immense chance que d'avoir connu et travaillé avec Annick.

Amar Halit

(Doctorant en études germaniques, ancien moniteur à la bibliothèque d'études germaniques) 